\title{
Growth-climate relations and the enhancement of drought signals in pedunculate oak (Quercus robur L.) tree-ring chronology in Eastern Hungary
}

\author{
Mátyás Árvai ${ }^{(1)}$, \\ András Morgós ${ }^{(2)}$, \\ Zoltán Kern ${ }^{(3)}$
}

\begin{abstract}
This paper presents an analysis of the climatic factors affecting tree-ring growth in pedunculate oak (Quercus robur L.), one of the most important species of Hungarian forests. A 221-year oak chronology was elaborated, covering the period 1789 to 2009 AD. The daily climate data for a $\sim 110$ year stretch offered a detailed insight into the climate-growth relations. The correlation function reached a maximum $(r>0.4)$ in the case of precipitation in MayAugust, providing evidence that water availability is the main factor driving the oak growth in the eastern part of the Great Hungarian Plain. Although there was no significant linear relation with temperature in the long term, moving window correlation analysis revealed that temperature response changed substantially over the course of the $20^{\text {th }}$ century. While positive correlation with winter temperature was characteristic in the first decades, later the response to summer temperature strengthened remarkably, reaching $r=-0.569$ by the end of the analysed period (years 1978-2007). While the vulnerability of oak to drought stress is common across Europe, in southern and central Europe high summer temperatures impair tree growth. The enhanced sensitivity of pedunculate oaks to the water balance in the eastern part of the Great Hungarian Plain allows to surmise the presence of an evolving tendency towards drought risk and vulnerability in the case of these oak stands.
\end{abstract}

Keywords: Dendroclimatology, Pedunculate Oak, Tree-rings, Hungary, Drought Signal

\section{Introduction}

Pedunculate oak (Quercus robur L.) is widely distributed across Europe (Ducousso \& Bordács 2004), where it is among the most economically important deciduous forest trees. Noble oaks (Q. robur and Q. petraea) are the most in-demand timber species in Hungary, thanks to their aes

(1) Institute for Soil Sciences and Agricultural Chemistry, Department of Soil Mapping and Environmental Informatics MTA, Budapest (Hungary); (2) Consart Ltd., Budapest (Hungary); (3) Institute for Geological and Geochemical Research, Research Centre for Astronomy and Earth Sciences MTA, Budapest (Hungary)

@ Mátyás Árvai (arvai.matyas@agrar.mta.hu)

Received: Jan 05, 2017 - Accepted: Jan 30, 2018

Citation: Árvai M, Morgós A, Kern Z (2018). Growth-climate relations and the enhancement of drought signals in pedunculate oak (Quercus robur L.) tree-ring chronology in Eastern Hungary. iForest 11: 267-274. - doi: 10.3832/ifor2348-011 [online 2018-03-29]

Communicated by: Jesus Julio Camarero thetic and technical qualities (Molnár \& Bariska 2002). Oak forests cover the second largest part of wooded areas in Hungary, and pedunculate and sessile oaks have the highest standing volume $(23.4 \%$ Tobisch \& Kottek 2013). The climate sensitivity of these two oak species is very similar (Dobrovolny et al. 2016), although Q. robur responds more strongly to water depletion than Q. petraea (Friedrichs et al. 2008).

The frequency of pedunculate oak can reach levels of $50-70 \%$ in forest stands in East Hungary, though habitat suitability is usually suboptimal (Eaton et al. 2016). Since local precipitation in the east Hungarian lowlands is usually insufficient to meet the water demand of the pedunculate oak (Führer et al. 2011), these oak forests depend on additional external water sources, such as groundwater (Móricz et al. 2012, Gribovszki et al. 2014). Subsurface salt accumulation, observed in this subhumid climate (Gribovszki et al. 2014, Tóth et al. 2014), should also be mentioned among the factors posing a challenge to growth and survival of oak stands in this region.

Despite its prominence in the silviculture of the region, relatively little is known about the response of the pedunculate oak to climate variability in Hungary. While the climate-growth relationships of the species have been intensively studied in the sur- rounding countries, such as Slovenia (Cufar et al. 2008, 2014), the Czech Republic (Dobrovolny et al. 2016), and Romania (Nechita et al. 2017), a single study has been conducted in eastern Hungary so far (Kern et al. 2013). However, a decline in pedunculate oak stands has been documented in many regions over its native range (Gentilesca et al. 2017, Helama et al. 2016). A detailed understanding of the effects of climate on oak growth is therefore an important task facing forest science over the entire range of the species.

Although eastern Hungary is not at the margin of the species' range (Fig. 1), its climatic conditions are somewhat outstanding. Indeed, in the last decades pedunculate oak stands at the border between Hungary and Romania have been affected by frequent droughts during all the four seasons, as pointed out by a recent analysis of European drought frequency and severity (Spinoni et al. 2017). The climatic signals affecting oak tree-ring growth in eastern-central Europe have been analysed in a recent study (Cufar et al. 2014). The easternmost sampling site (Uog) of a large study network was in eastern Hungary, where 12 tree-ring samples covering the period 1847-2001 were analyzed. The main patterns of variability among oak tree-ring chronologies across the network were evaluated by multivariate techniques, high- 
lighting a distinct degree of variability at the Uog site. Correlation analysis based on monthly climate records over a 60 year period (1935-1995) revealed a positive correlation with precipitation occurring in previous December, as well as June and August of the current year, while a lack of correlation with monthly temperature records was observed for the east Hungarian oak chronology.

In the present study we extended the above oak tree-ring dataset regarding the Uog site by sampling 25 living trees and 3 dead stems collected between 2001 and 2009 near Debrecen (Hungary), and by analyzing a 221-year oak chronology covering the period 1789-2009 AD. We analyzed such extended data set, along with a homogenised daily climate data from the nearby meteorological station over a period of $\sim 110$ years, with the aim of obtain ing more detailed insights into the correlation between climate and the growth of pedunculate oak stands. Variable temporal width and moving correlations on daily climate data (Beck et al. 2013) were employed to account for short- and long-term climate influences on radial oak growth.

The present investigation contributes to improve our understanding of the spatial variability of the climatic response of oak trees in East-Central Europe (Cufar et al. 2014), and provides information on the sensitivity of this important European forest species to climatic variability.

\section{Materials and methods}

\section{Study site}

The sampling sites were located in managed forests of the eastern part of the Great Hungarian Plain, in the Great Forest of Debrecen (Debreceni Nagyerdö), near the city of Debrecen, Hungary (Fig. 1). The
Great Forest of Debrecen is the first natural reserve established in Hungary in 1939, and is one of the last natural sandy oak forest habitats with Lily-of-the-valley (Convallario-Quercetum roboris) in the country, where oaks grow in sparse forest patches surrounded by wooded steppe vegetation of sandy grasslands. The dominant species is the pedunculate oak (Quercus robur L.), along with the field maple (Acer campestre - Török \& Tóthmérész 2004). The soil is mostly humic sandy soil with sporadic patches of brown earth on sand and banded brown forest soils (Pásztor et al. 2018); the corresponding WRB units are Arenosols and Luvisols, respectively (Michéli et al. 2014).

Based on homogenized monthly climate data from the local meteorological station $\left(47^{\circ} 31^{\prime} \mathrm{N}, 21^{\circ} 38^{\prime} \mathrm{E}\right.$, elevation $121 \mathrm{~m}$ a.s.l.), the mean annual air temperature is $9.8^{\circ} \mathrm{C}$, and annual precipitation is $565 \mathrm{~mm}$ for the period 1961-1990 (OMSZ 2016). January is the coldest month (average temperature $-2.6{ }^{\circ} \mathrm{C}$ ), and July the warmest $\left(+20.3{ }^{\circ} \mathrm{C}\right)$. Rainfall shows a seasonal peak in June (80 $\mathrm{mm}$ ), while the driest months are February and October $(35 \mathrm{~mm})$. Such climatic data support the marginal suitability of the area with regard to the autoecology of pedunculate oak (Eaton et al. 2016), as local rainfall hardly meets oak water demand in this region (Führer et al. 2011).

Based on annual climatic data for Debrecen, in the Great Forest the mean annual air temperature increased until the early 1930s, while a second significant increase was observed since the late 1980 os (Fig. 2). Relatively wet conditions prevailed during the 1910s, and the total annual precipitation slightly decreased until the early 1990s. A regional evaluation of the climate trends also confirmed that the eastern part of the Great Hungarian Plain (including the study sites) significantly warmed up and became drier (to some extent) over the course of the $20^{\text {th }}$ century (Breuer et al. 2017).

\section{Sample collection}

Cross-sectional disk samples were obtained from 15 living trees and 3 dead stems collected at several sites in the Great Forest of Debrecen between 2001 and 2004. Additionally, the 12 samples used to build the aforementioned Uog chronology (Cufar et al. 2014) were included in the collection. We updated such chronology by including 10 additional cross-sectional disk samples from dominant pedunculate oak trees recently harvested at a nearby site (13 km southward - Fig. 1) in August 2009.

\section{Sample preparation and measurement}

The collected cross-sectional disks were sanded and polished before tree-ring analysis. Ring width measurements were performed at a resolution of $0.01 \mathrm{~mm}$ along two radii per disk using a LINTAB measuring table and TSAP-Win software (Rinn 2005). Ring width series were synchronized, initially by visual comparison (Stokes \& Smiley 1996), and then checked using the software COFECHA (Holmes 1983). Measurement and crossdating were performed using the facilities available at the Budapest Tree-Ring Laboratory, Dept. of Palaeontology, Eötvös Loránd University, Budapest, Hungary (Kázmér \& Grynaeus 2003). Standard dendrochronological statistics such as the percentage of agreement (Gleichläufigkeit, glk \% - Eckstein \& Bauch 1969) and modified $t$ value ( $t_{B P}$ - Baillie \& Pilcher 1973) were used to evaluate the results of crossdating.

\section{Tree-ring chronology standardisation}

In order to remove age-related trends

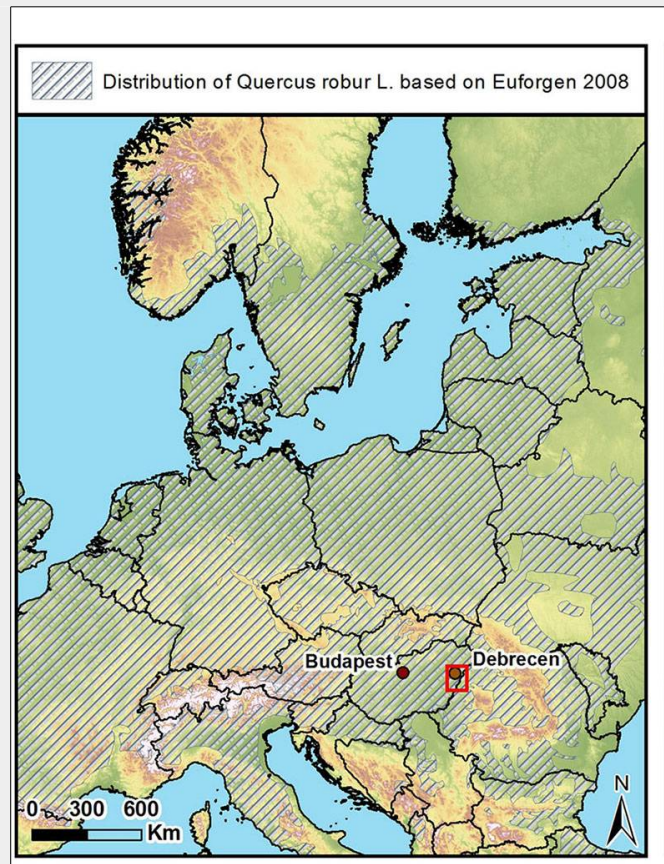

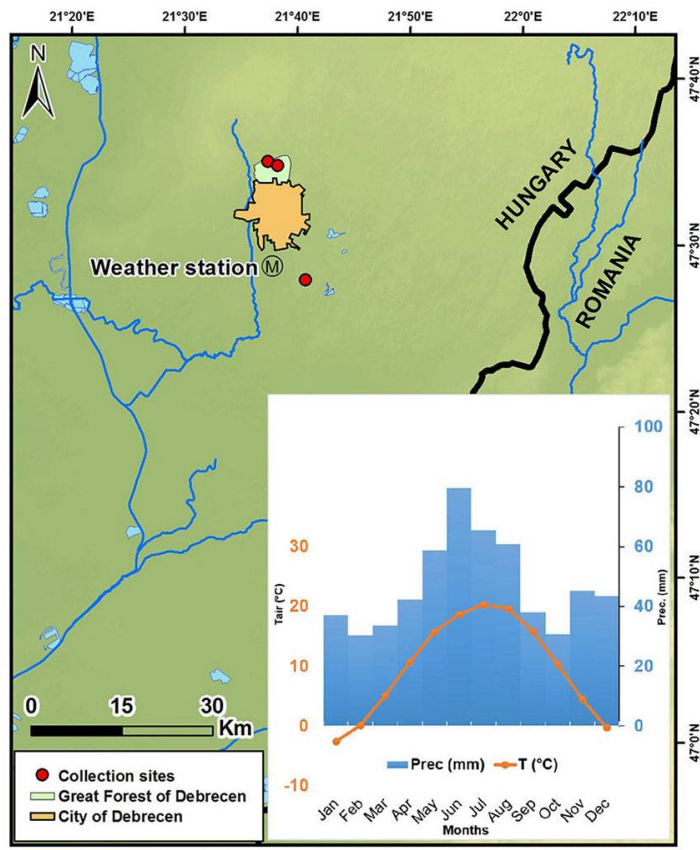

$21^{\circ} 50^{\circ} \mathrm{E}$

$22^{2} 0^{\circ}$

$22^{\circ} 10^{\circ} \mathrm{E}$

Fig. 1 - Location of the sampling sites. The map on the left shows the study area (red rectangle), along with the European distribution of pedunculate oak (Quercus robur L.). The right panel is a close-up view of the study area with the sampling sites and a Walter-Lieth climate diagram (inset chart) of the Debrecen meteorological station, based on daily data from the 1961-9o reference period. 


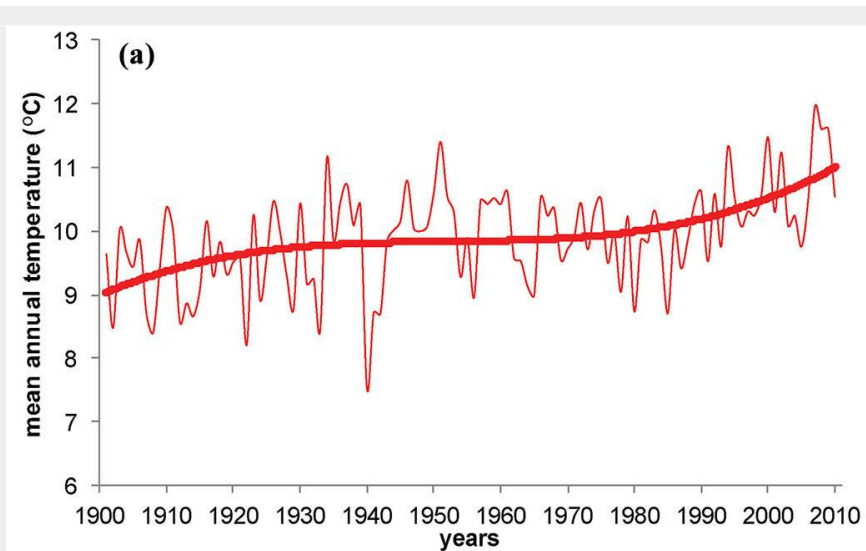

(b)

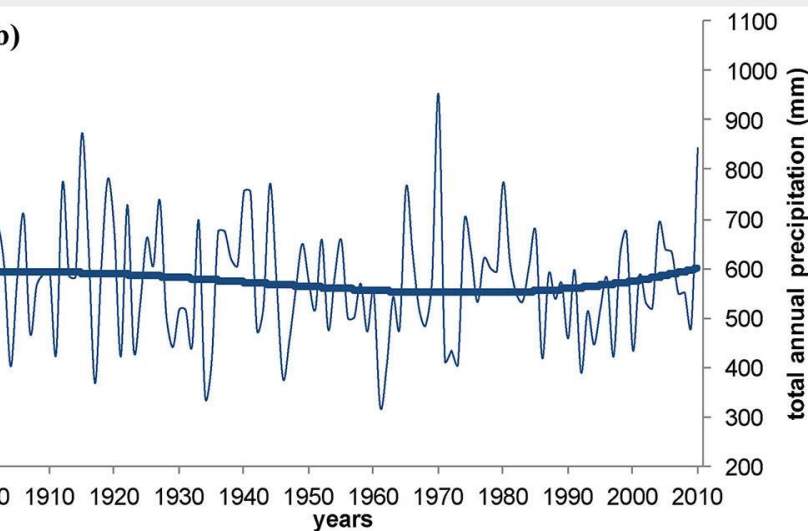

Fig. 2 - Mean annual temperature (a) and total annual precipitation (b) for the period 1901-2010 at Debrecen (Hungary) based on data from the Hungarian National Meteorological Service. Long-term changes are shown by $3^{\text {rd }}$-order polynomial trends (thicker lines).

and growth disturbances resulting from forest dynamics, tree-ring chronologies were standardised (Cook et al. 1990). A cubic spline with a $50 \%$ frequency cut-off at two-thirds of the series length was fitted (Cook \& Peters 1981) and an index was calculated as the ratio of the raw ring width data to the spline.

The mean chronology was calculated as a bi-weight robust mean and the "ars" chronology was selected, because the retained population-level autocorrelation is considered to be related to climatic variability (Cook 1985). The stability of the chronological signal preserved in the index series was checked using the Expressed Population Signal (EPS) statistical method. EPS estimates how well a finite number of analysed samples represents the theoretical stand average; the widely accepted threshold is 0.85 (Wigley et al. 1984). Mean interseries correlation (Rbar) and EPS were calculated using 41-yrs running windows. Variance adjustment was applied to minimize variance bias due to changing sample replication and the effect of fluctuating interseries correlation (Osborn et al. 1997).

\section{Climate data and statistical analyses}

Quality-checked and homogenized data of daily precipitation and temperature were obtained from the local meteorological station in Debrecen (Fig. 1) covering the period from January $1^{\text {st }}, 1901$ to December $31^{\text {th }}, 2010$ (OMSZ 2016). The CLIMTREG software (Beck et al. 2013) was used to assess the correlation of climatic variables with tree growth. CLIMTREG scans daily climate data using variable temporal windows requiring no monthly limits. The correlation analysis was performed on daily mean temperature and daily precipitation totals, starting from July of the previous year up to $31^{\text {st }}$ October of the current year ( 488 days), grouped in segments of at least 21 days (three weeks) up to a maximum of 121 days (four months). Besides the assessment of the long-term mean climate response, a 31-yrs moving window correlation analysis was applied to test for the temporal stability of the climatic signal.

Finally, monthly potential evapotranspiration (PET - Thornthwaite 1948) and the difference between monthly precipitation and evapotranspiration (P-PET) was calculated for the Debrecen station. The P-PET parameter was considered as an estimate of the climatic water balance (Rozas 2015).

\section{Results}

\section{The 221-year oak tree-ring width} chronology

The chronology obtained from the trees sampled at the Great Forest sites was in good agreement with the chronology constructed from the initial 12 oak trees representing the Debrecen site in the former network study (site code Uog - Cufar et al. 2014), which evaluated the common climatic signals in oak tree rings in SE Central
Europe (Fig. 3). Since climatological and soil conditions were relatively homogeneous among stands, the initial Uog data set and the newly collected data set were merged to develop an improved regional Q. robur ring-width chronology. However, two out of the 12 series of the initial Uog data set were discarded as they showed a low degree of correlation in their juvenile decades when the entire dataset was tested using COFECHA. Therefore, only ten series were retained from the Uog data set in the final chronology.

The final tree-ring width (TRW) chronology obtained from the merged data set spans over the period 1789-2009, including at least 5 trees with data from 1809 (Fig. 4). The ten samples originating from the newly added site had the effect of moving forward the latest date of the chronology by 8 years, while the historic earliest date

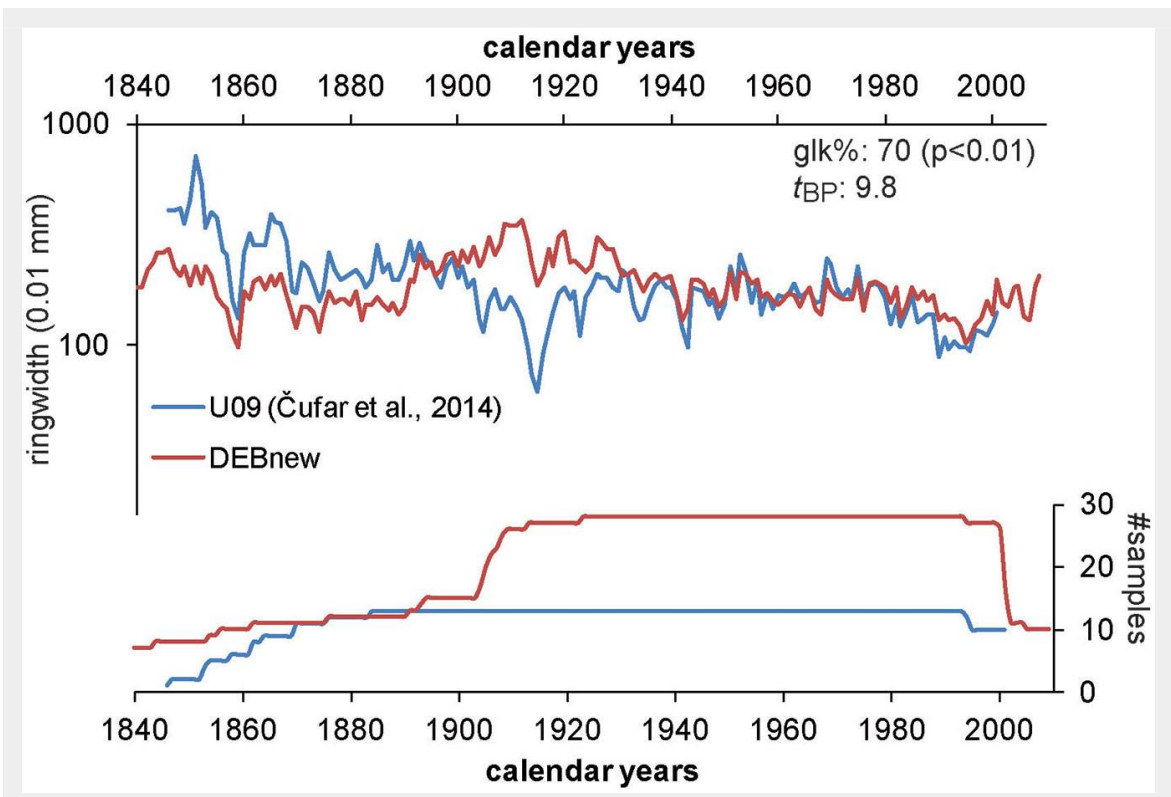

Fig. 3 - Comparison of the former Debrecen tree-ring width chronology (site code Uo9 in Cufar et al. 2014) with the new records. Basic crossdating statistics are shown, such as the percentage of agreement (GLK\% - Eckstein \& Bauch 1969) and $t_{\mathrm{BP}}$ (Baillie \& Pilcher 1973). 


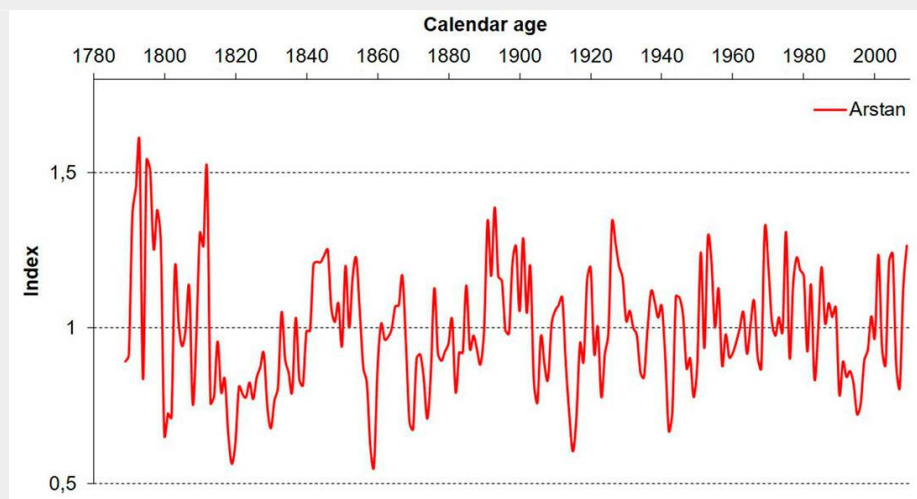

(A)

Fig. 4 - Indices and signal strength statistics of the regional pedunculate oak chronology. (A) Tree-ring width indices. (B) Signal strength statistics calculated in 41-year running windows: (EPS) Expressed Population Signal (Wigley et al. 1984), (Rbar) between-tree correlation. The grey dashed line represents the 0.85 EPS threshold. (C) The replication of the chronology (number of trees analysed) over the study period (1789-2009 AD).
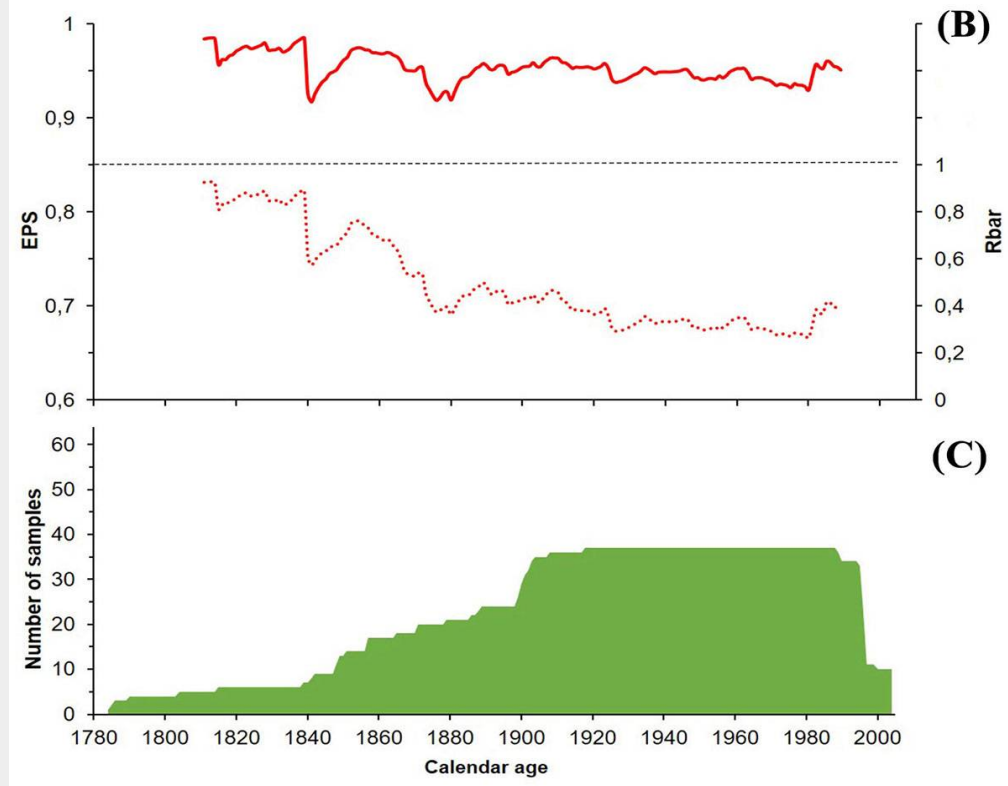

(C)

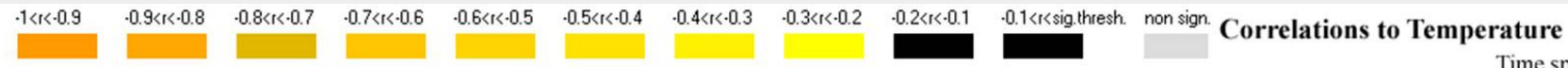

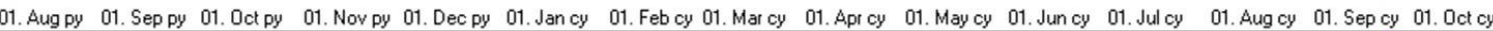

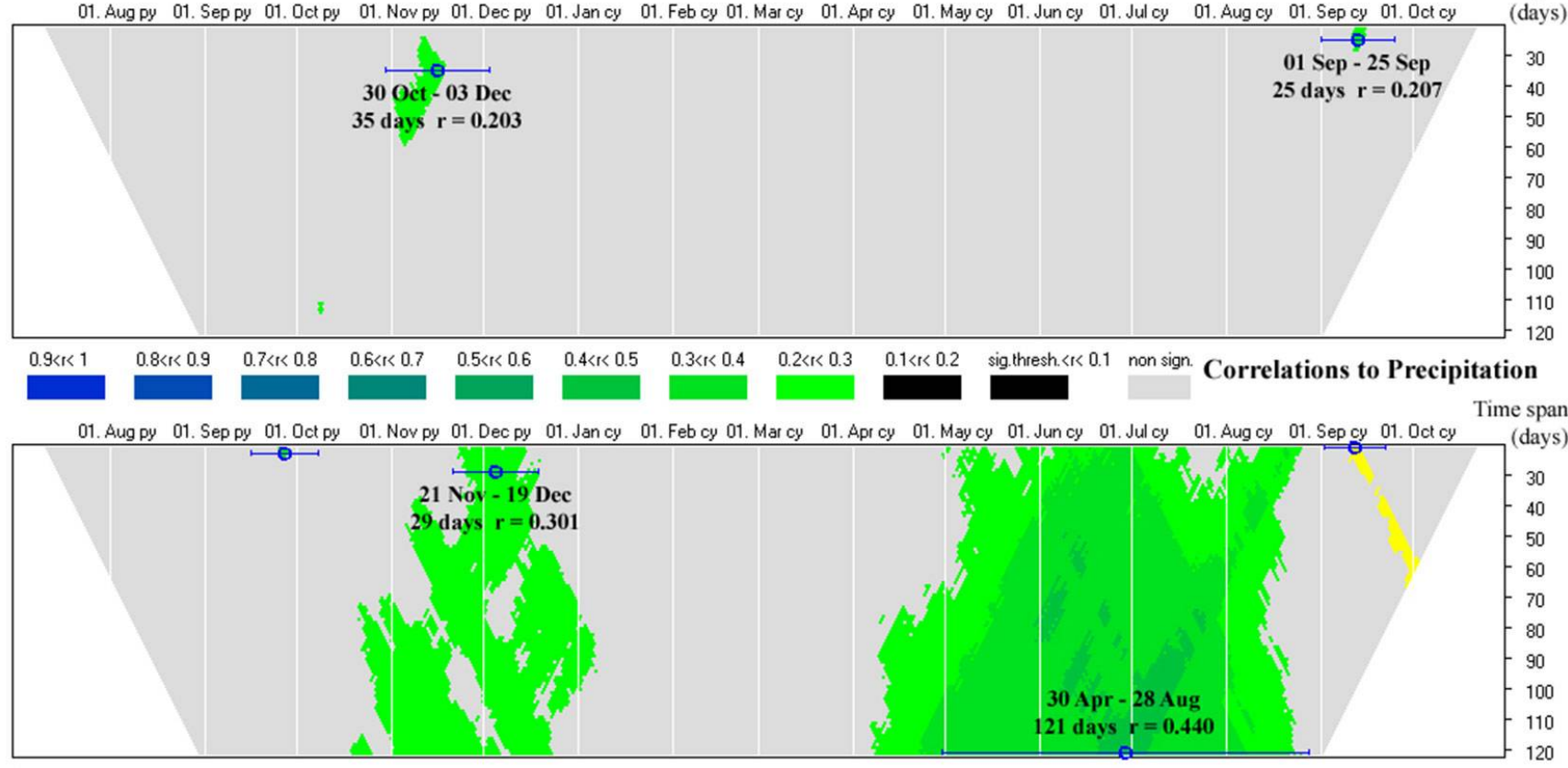

Fig. 5 - Results of the correlation analysis between tree growth and daily climate data over the period 1901-2010. The centres of the time intervals which correlate at the highest degree with the tree-ring index are indicated by circles, and the beginning and the end of the corresponding time intervals are indicated by horizontal bars. Top panel: relationship between oak growth index and daily temperature. Bottom panel: relationship between oak growth index and daily precipitation. The colour coding for the significance level of correlations is reported above and below the top graph. White vertical lines highlight the first day of each month. 


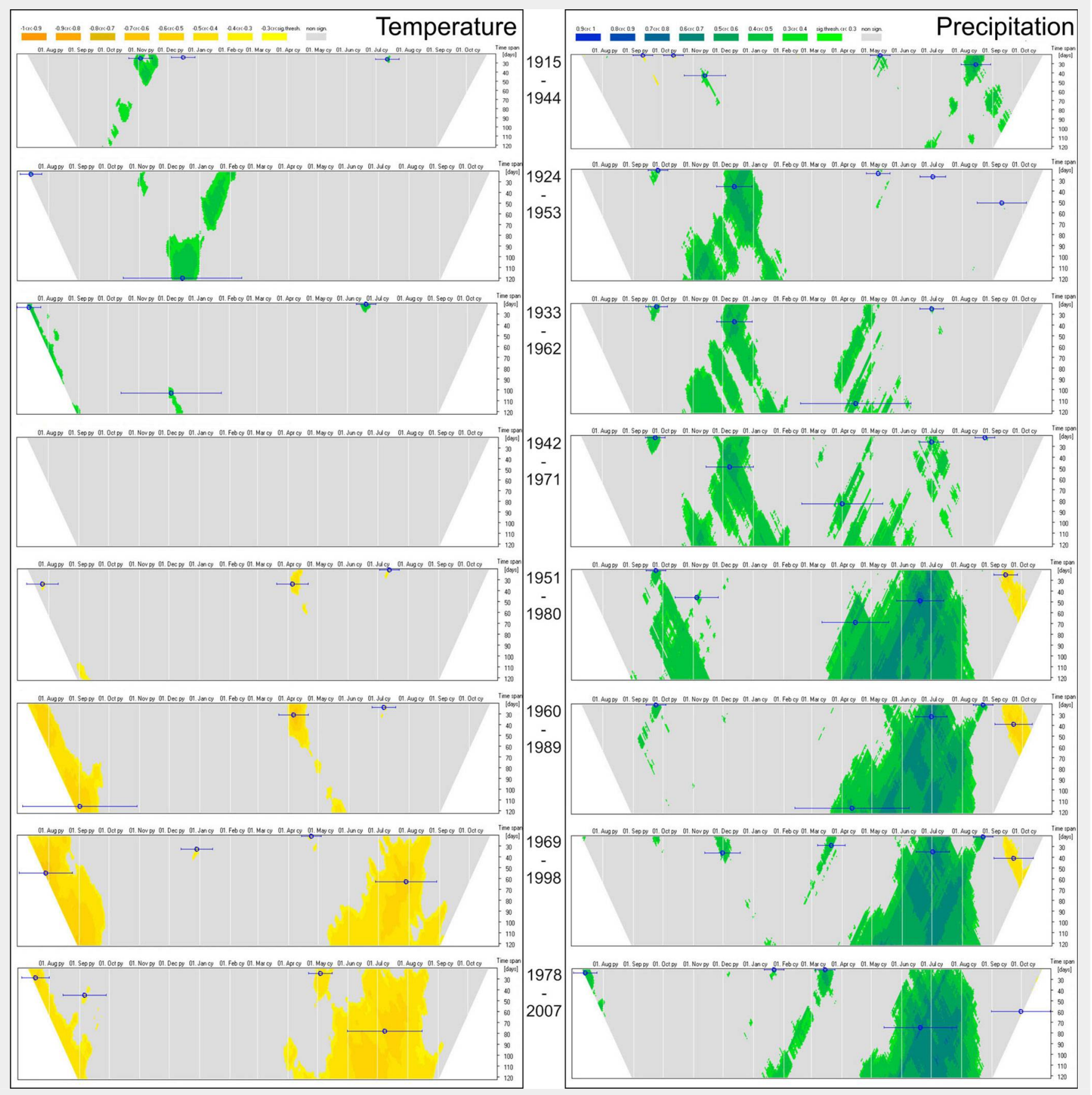

Fig. 6 - Subset of the results of the correlation analysis between tree growth and daily climate data, calculated in 31-yrs moving windows over the period 1901-2010 (left: temperature, right: precipitation). The animated full set of correlation charts can be found in Movie $\mathrm{S} 1$ in the Supplementary materials. For further details see the caption to Fig. 4.

was extended back by more than 50 years. The signal strength statistics confirmed the exceptionally robust chronological signal, as EPS was well above the 0.85 level (Fig. 4.).

\section{Relations between pedunculate oak radial increment and climate}

Climate-growth analysis using daily climate data provided a detailed picture of the long-term mean climate sensitivity of the pedunculate oak in east Hungary. A significant $(p<0.01)$ positive correlation was found between the interannual variation in oak growth and summer precipitation (Fig.
5). The highest response $(r=0.440, p<$ 0.001 ) was found in the case of summer precipitation (30 April - 28 August). A secondary peak of correlation $(r=0.296, p=$ 0.002 ) was observed with the preceding late autumn-early winter precipitation (20 November - 18 December). Much weaker correlations were detected between oak growth and temperature, which proved to be significant in one case $(r=0.207, p=0.03)$ with a period of $\sim 1$-month ( 1 to 25 September - Fig. 5).

In order to gain an insight into the temporal stability of the growth-climate relationship, the correlation analysis was per- formed using a 31-yrs moving window. The results revealed that the sensitivity of oak growth to precipitation during the growing season has generally persisted over the past $\sim 110$ years, although the peak correlation has moved within the warm season in the course of the past century (Fig. 6). The full results of the moving window correlation analysis are available in animated form in the Supplementary material (Movie S1).

A first peak in correlation was found with a 25-day period (13 May - 10 July - $r=0.783$, $\mathrm{p}<0.001$ ) between 1955 and 1984, and a second peak was observed for a much longer period (106 days between 13 May 


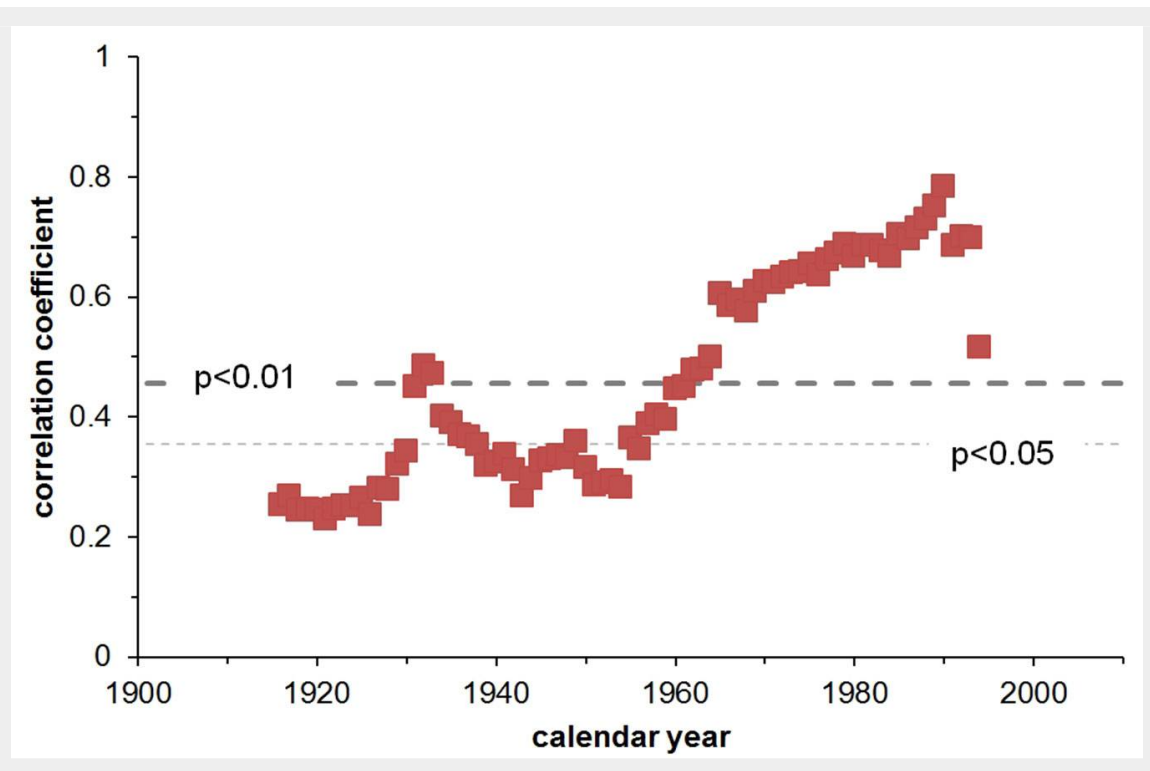

Fig. 7 - Results of the 31-yrs moving window correlation analysis between the MarchAugust water deficit (P-PET) and interannual variation in ring width index of pedunculate oaks from the Great Forest of Debrecen. The thin and thick horizontal dashed lines represent the $p=0.05$ and $p=0.01$ significance levels, respectively.

and 26 August $-r=0.757, p<0.001$ ) between 1975 and 2004. The positive correlation with the amount of precipitation during the dormant season was detected only until the 1950s, and the correlation found for the winter season occasionally exceeded the correlation found for the corresponding growing season (e.g., 1924-1953 - Fig. 6).

The response of oak growth to temperature has substantially changed over the past century. Positive correlations with the mean temperature in the dormant season could be detected over the first half of the $20^{\text {th }}$ century, peaking in the period 1918 $1947(r=0.494, p=0.005)$, while a negative correlation with late-spring temperatures emerged from 1943 onwards, and with mid-summer temperatures from the mid1950 s. The correlation with spring temperature peaked between 1955 and 1984 (21 Mar - 22 Apr - r=-0.637, $p<0.001$ ), while the correlation with summer temperature ( 31 May - 16 Aug) reached a peak ( $r=-0.569$, $\mathrm{p}<0.001)$ slightly before the end of the analysed period (1978-2007 - Fig. 6, see also Movie S1 in Supplementary material). In addition, an inverse linear relation emerged with previous summer temperatures since the mid-1950s.

The changing correlation of tree growth with temperature along the last century reflects a substantial change in the response of the studied stands to drought. A similar 31-yrs moving window correlation analysis carried out on the average P-PET in the period March-August revealed a weak positive correlation between interannual drought variability and radial oak increment in the first half of the $20^{\text {th }}$ century (Fig. 7.). However, the correlation gradually increased thereafter, exceeding the $p=0.05$ level by $\sim 1960$, and culminating between 1975 and $2005(r=0.780, p<0.001)$.

\section{Discussion}

The present study provides the first highresolution tree-ring based growth-climate analysis using daily meteorological data in Hungary. These results provide evidence that water availability is the main factor driving the oak stand growth in the eastern part of the Great Hungarian Plain. The longterm growth-climate relationship detected in this study is in agreement with previous results reported for this region (Cufar et al. 2014). However, the previous study considered a much shorter period of time using a dataset with significantly poorer replication (Cufar et al. 2014). Moreover, our findings are broadly comparable with the results of similar investigation on oak dendroecology carried out in the surrounding countries, such as Hungary (Kern et al. 2013), Slovenia (Cufar et al. 2008), Romania (Nechita et al. 2017), Serbia (Stojanović et al. 2015) and Slovakia (Prokop et al. 2016). Furthermore, limitations of pedunculate oak growth due to summer water availability has been widely described throughout its European range, from the British Isles (Pilcher \& Gray 1982) to Sweden (Drobyshev et al. 2008), Estonia (Sohar et al. 2014), Finland (Helama et al. 2016), and the Czech Republic (Dobrovolny et al. 2016).

The growth-climate relationship, however, has varied over the past 110 years. The positive response of oak trees to summer precipitation gradually strengthened, and was accompanied by a positive correlation with both precipitation and temperature in the winter season in the first decades of the $20^{\text {th }}$ century. The growth-climate correlation reported for southern
Poland (Wazny \& Eckstein 1991) or Moldavia (Nechita et al. 2017) is similar to the oak response in East Hungary for the first part of the $20^{\text {th }}$. However, it is worth noting that the stimulating effect of winter precipitation and temperature on oak growth was not detected in the course of the second half of the $20^{\text {th }}$ century; instead, a negative correlation with temperature during the growing season was detected. These findings are more similar to the results reported from NW Romania (Nechita et al. 2017), the Czech Republic (Rybníček et al. 2016) or Germany (Friedrichs et al. 2008). The contrasting growth-climate relations between the early and late $20^{\text {th }}$ century observed in the eastern part of the Great Hungarian Plain recall the patterns found in pedunculate oak stands living nearby water-saturated (i.e., floodplain) and reference sites (Tumajer \& Treml 2016). In this case, a positive effect of temperature on the growth of floodplain trees was observed for temperatures recorded at previous October and from January to March, with no significant response to drought in the growing season; by contrast, a high positive dependence of drought variability from the previous November onwards, peaking in the growing season, was observed at reference sites (Tumajer \& Treml 2016). The overall picture of the evolution of growth-climate correlations in the studied stands (Fig. 6, Fig. 7) is similar to that of water-saturated habitats, which shifted by the end of the $20^{\text {th }}$ century to the droughtlimited growth, as usually reported from the broader region of central Europe. Indeed, a recent geostatistical evaluation of the multidecadal variations of the groundwater level in the north-eastern part of the Great Hungarian Plain (Garamhegyi et al. 2017) supports the presumption of the changes in the soil moisture availability. A significant drop (average - $0.5 \mathrm{~m}$ ) was detected in groundwater levels at $89 \%$ of the 216 shallow groundwater wells examined in the region of interest, while the interpolated groundwater level in the surroundings of the Great Forest of Debrecen was found to be in the range -0.3 to $-0.4 \mathrm{~m}$ (Garamhegyi et al. 2017). Therefore, we hypothesize that the enhanced drought sensitivity of pedunculate oak stands in the studied region could be likely the consequence of the interaction between the decreased groundwater table and warmer summer air temperatures which, in turn, may amplify water demand or lengthen the duration of the water-deficit period.

Temporal changes in climate sensitivity have also been reported for other oak stands in Europe (Dobrovolny et al. 2016). The gradual loss of the dominant precipitation signal in Bohemian and Moravian oak TRWs (Dobrovolny et al. 2016) has been explained by changes in precipitation seasonality, leading to an altered soil moisture regime (Rybníček et al. 2016) and/or air pollution (Dobrovolny et al. 2016). Water regime changes and air temperature in- 
creases have been found to play a key role in the growth regulation of floodplain pedunculate oak forests in Serbia (Stojanović et al. 2015) and Slovenia (Cater \& Levanič 2004).

Increasing drought risk is an important issue for Central European forests (Hlásny et al. 2014). Water limitation may be a critical constraint to primary productivity under future scenarios in which more arid climatic conditions prevail. It has been observed that pedunculate oak trees can endure drought conditions over short periods owing to osmotic adaptation under water stress (Cater 2011). However, climate change is likely to increase the frequency and length of summer drought in this region (Bartholy et al. 2007, Gálos et al. 2012), which may well pose a greater challenge to oak forests in the future. Increasing drought and temperature sensitivity have been recently reported in Central Europe for other important forest species (Fagus sylvatica, Picea abies) as well, particularly for species which had already experienced unprecedented forest declines (Kolár et al. 2017). These evidences suggest a significant impact of the predicted climate change on Central European forest ecosystems. The projected drought exposure of Central Europe describes the anticipated dynamics of the regional forests, and identifies measures for facilitating the adaptation of forests to climate change-induced drought risk (Hlásny et al. 2014).

Besides the variable climate signal in the ring width record, the newly developed 221-year oak chronology extending back to the late $18^{\text {th }}$ century might also serve as a dating tool for dendroarchaeological research in the region. In addition, earlywood vessel anatomy parameters (average vessel lumen area and total vessel lumen area) shared a temperature signal common to both the floodplain and reference site (Tumajer \& Treml 2016). This suggests that these parameters are less sensitive to longterm changes in hydrological status of the soil, thus representing promising candidate parameters in tests for robust and timestable dendroclimatological signals in future climate reconstruction efforts in the oak forests of the Great Hungarian Plain.

\section{Conclusions}

This is the first study on the association between the growth of pedunculate oak stands and intra-annual climate parameters in the eastern part of the Great Hungarian Plain. The novel approach employed, using moving correlations of the tree-ring chronology, revealed a mixed climatic signal over the last century. The strong chronological signal, the inclusion of an additional site, and the remarkable improvement in the degree of replication, make the oak chronology developed in this study a significantly improved regional oak reference data set.

The correlation analysis on growth-climate relationship revealed a relatively strong response of oak trees to precipitation during the growing season. While a significant positive correlation of tree growth with winter temperature could be detected over the first half of the $20^{\text {th }}$ century, a negative correlation emerged with late-spring temperature from the early 1960 s, gradually strengthening until it covered the entire summer season by the end of the $20^{\text {th }}$ century.

\section{Acknowledgements}

We thank the "Lendület" program of the Hungarian Academy of Sciences (LP201227/2012) for the support received during the study. This is contribution no. 54 of the "2ka Palæoclimatology" Research Group and no.32 of the Budapest Tree-Ring Laboratory.

\section{References}

Baillie MGL, Pilcher JR (1973). A simple cross-dating programme for tree-ring research. TreeRing Bulletin 33: 7-14.

Bartholy J, Pongrácz R, Gelybó G (2007). Regional climate change expected in Hungary for 2071-2100. Applied Ecology and Environmental Research 5 (1): 1-17. - doi: 10.15666/aeer/0501_0 01017

Beck W, Sanders TG, Pofahl U (2013). CLIMTREG: detecting temporal changes in climate-growth reactions-a computer program using intraannual daily and yearly moving time intervals of variable width. Dendrochronologia 31 (3): 232241. - doi: 10.1016/j.dendro.2013.02.003

Breuer H, Acs F, Skarbit N (2017). Climate change in Hungary during the twentieth century according to Feddema. Theoretical and Applied Climatology 127: 853-863. - doi: 10.1007/s00704015-1670-0

Cater M, Levanič T (2004). Increment and environmental conditions in two Slovenian pedunculate-oak forest complexes. Ekológia (Bratislava) 23 (4): 353-365. [online] URL: http:// www.researchgate.net/publication/256441974

Cater M (2011). Osmotic adaptation of Quercus robur L. under water stress in stands with different tree density - relation with groundwater table. Dendrobiology 65: 29-36. [online] URL: http://agro.icm.edu.pl/agro/element/bwmeta1. element.agro-210b7ee5-1066-435a-9680-

2bfed69a5fce/c/65_29_36.pdf

Cook ER, Peters K (1981). The smoothing spline: a new approach to standardizing forest interior tree-ring width series for dendroclimatic studies. Tree-Ring Bulletin 41: 45-53. [online] URL: http://hdl.handle.net/10150/261038

Cook ER (1985). A time series analysis approach to tree-ring standardization. PhD thesis, The University of Arizona, Tucson, USA, pp. 171. [online] URL: http://hdl.handle.net/10150/188110 Cook ER, Briffa K, Shiyatov S, Mazepa V (1990). Tree-ring standardization and growth-trend estimation. In: "Methods of Dendrochronology" (Cook E, Kairiukstis L eds). Applications in the Environmental Sciences, Kluwer Academic Publishers, Netherlands, pp. 104-162.

Cufar K, De Luis M, Eckstein D, Kajfez-Bogataj L (2008). Reconstructing dry and wet summers in SE Slovenia from oak tree-ring series. International Journal of Biometeorology 52: 607-
615. - doi: 10.1007/s00484-008-0153-8 Cufar K, Grabner M, Morgós A, Del Castillo EM, Merela M, De Luis M (2014). Common climatic signals affecting oak tree-ring growth in $\mathrm{SE}$ Central Europe. Trees 28 (5): 1267-1277. - doi: 10.1007/s00468-013-0972-z

Dobrovolny P, Rybníček M, Büntgen U, Trnka M, Brázdil R, Stachon Z, Prokop O, Kolár T (2016). Recent growth coherence in long-term oak (Quercus spp.) ring width chronologies in the Czech Republic. Climate Research 70: 133-141. doi: $10.3354 /$ cro1402

Drobyshev I, Niklasson M, Eggertsson O, Linderson $\mathrm{H}$, Sonesson K (2008). Influence of annual weather on growth of pedunculate oak in southern Sweden. Annals of Forest Science 65 (5): 512. - doi: 10.1051/forest:2008033

Ducousso A, Bordács S (2004). EUFORGEN Technical Guidelines for genetic conservation and use for pedunculate and sessile oaks (Quercus robur and Quercus petraea). International Plant Genetic Resources Institute, Rome, Italy, pp. 6. [online] URL: http://books.google.com/books? id=ioYQ8P21T4WC

Eaton E, Caudullo G, Oliveira S, De Rigo D (2016). Quercus robur and Quercus petraea in Europe: distribution, habitat, usage and threats. In: "European Atlas of Forest Tree Species" (SanMiguel-Ayanz J, De Rigo D, Caudullo G, Houston Durrant T, Mauri A eds). Publications Office of the EU, Luxembourg, pp. 160-163. [online] URL: http://www.researchgate.net/publication/2994 71357

Eckstein D, Bauch J (1969). Beitrag zur rationalisierung eines dendrochronologischen verfahrens und zur analyse seiner aussagesicherheit $[A$ contribution to rationalization of a dendrochronological procedure and to analyse the statistical validity]. Forstwissenschaftliches Centralblatt 88 (4): 230-250. [in German] - doi: 10.1007/BF02741777

EUFORGEN (2009). Distribution map of pedunculate oak (Quercus robur). Web site. [online] URL: http://www.euforgen.org/species/quercu s-robur/

Friedrichs DA, Büntgen U, Frank DC, Esper J, Neuwirth B, Löffler J (2008). Complex climate controls on 2oth century oak growth in CentralWest Germany. Tree Physiology 29: 39-51. - doi: 10.1093/treephys/tpno03

Führer E, Horváth L, Jagodics A, Machon A, Szabados I (2011). Application of a new aridity index in Hungarian forestry practice. Idöjárás (Quarterly Journal of the Hungarian Meteorological Service) 115 (3): 205-216.

Garamhegyi T, Kovács J, Pongrácz R, Tanos P, Hatvani IG (2017). Investigation of the climatedriven periodicity of shallow groundwater level fluctuations in a Central-Eastern European agricultural region. Hydrogeology Journal 407 (1-4): 28. - doi: 10.1007/s10040-017-1665-2

Gentilesca T, Camarero JJ, Colangelo M, Nolè A, Ripullone F (2017). Drought induced oak decline in the western Mediterranean region: an overview on current evidences, mechanisms and management options to improve forest resilience. iForest 10: 796-806. - doi: 10.3832/ifor 2317-010

Gribovszki Z, Kalicz P, Balog K, Szabó A, Tóth T (2014). Comparison of an oak forest and of a pasture groundwater uptake and salt dynamics 
on the Hungarian Great Plain. Acta Silvatica et Lignaria Hungarica 10: 103-114. - doi: 10.2478/ aslh-2014-0008

Gálos B, Hänsler A, Kindermann G, Rechid D, Sieck K, Jacob D (2012). The role of forests in adapting to climate change - a case study for Europe. Acta Silvatica et Lignaria Hungarica 8: 87-102. - doi: 10.2478/v10303-012-0007-2

Helama S, Sohar K, Läänelaid A, Mäkelä HM, Raisio J (2016). Oak decline as illustrated through plant-climate interactions near the northern edge of species range. Botanical Review 82: 1-23. - doi: 10.1007/s12229-016-9160-3 Hlásny T, Mátyás C, Seidl R, Kulla L, Merganičová K, Trombik J, Dobor L, Barcza Z, Konôpka B (2014). Climate change increases the drought risk in Central European forests: what are the options for adaptation? Forestry Journal 60 (1): 5-18. - doi: 10.2478/forj-2014-0001

Holmes RL (1983). Computer-assisted quality control in tree-ring dating and measurement. Tree-ring Bulletin 44: 69-75. [online] URL: http://hdl.handle.net/10150/261223

Kern Z, Patkó $M$, Kázmér $M$, Fekete J, Kele S, Pályi Z (2013). Multiple tree-ring proxies (earlywood width, latewood width and $\delta^{13} \mathrm{C}$ ) from pedunculate oak (Quercus robur L.), Hungary. Quaternary International 29: 257-267. - doi: 10.1016/j.quaint.2012.05.037

Kolár T, Cermák P, Trnka M, Zid T, Rybníček M (2017). Temporal changes in the climate sensitivity of Norway spruce and European beech along an elevation gradient in Central Europe. Agricultural and Forest Meteorology 239: 24-33. - doi: 10.1016/j.agrformet.2017.02.028

Kázmér M, Grynaeus A (2003). The Budapest tree-ring laboratory. Association for Tree-Ring Research Newsletter 1: 5-6.

Michéli E, Fuchs M, Láng V, Szegi T, Kele G (2014). Methods for modernizing the elements and structure of the Hungarian Soil Classification System. Agrokémia és Talajtan 63 (1): 6978. - doi: 10.1556/Agrokem.63.2014.1.8

Molnár S, Bariska M (2002). Magyarország ipari fái [Wood species of Hungary]. Szaktudás Kiadó Ház, Budapest, Hungary, pp. 168-175.

Móricz N, Mátyás C, Berki I, Rasztovits E, Vekerdy Z, Gribovszki Z (2012). Comparative water balance study of forest and fallow plots. iForest 5: 188-196. - doi: 10.3832/iforo624-005 Nechita C, Popa I, Eggertsson O (2017). Climate response of oak (Quercus spp.), an evidence of a bioclimatic boundary induced by the Carpathians. Science of the Total Environment 599-600:
1598-1607. - doi: 10.1016/j.scitotenv.2017.05.118 OMSZ (2016). National Meteorological Service of Hungary, website. [online] URL: http://www. met.hu/zip_downloads.php?fn=/eghajlat/ma gyarorszag_eghajlata/eghajlati_adatsorok/Debr ecen/adatok/eghajlati_adatsor_Debrecen19012010.zip

Osborn TJ, Briffa KR, Jones PD (1997). Adjusting variance for sample-size in tree-ring chronologies and other regional-mean time-series. Dendrochronologia 15: 89-99. [online] URL: http:// ueaeprints.uea.ac.uk/33968/1/osborn_et_al_var iance_adjustment_dendrochronologia1997.pdf Pilcher JR, Gray B (1982). The relationships between oak tree growth and climate in Britain. Journal of Ecology 70: 297-304. - doi: 10.2307/ 2259880

Prokop O, Kolár T, Büntgen U, Kyncl J, Kyncl T, Bošela $M$, Choma $M$, Barta $P$, Rybníček $M$ (2016). On the palaeoclimatic potential of a millennium-long oak ring width chronology from Slovakia. Dendrochronologia 40: 93-101. - doi: 10.1016/j.dendro.2016.08.001

Pásztor L, Laborczi A, Bakacsi ZS, Szabó J, Illés G (2018). Compilation of a national soil-type map for Hungary by sequential classification methods. Geoderma 311: 93-108. - doi: 10.1016/j.geo derma.2017.04.018

Rinn F (2005). TSAP reference manual. Rinntech, Heidelberg, Germany, pp. 262.

Rozas V (2015). Individual-based approach as a useful tool to disentangle the relative importance of tree age, size and inter-tree competition in dendroclimatic studies. iForest 8: 187194. - doi: 10.3832/ifor1249-007

Rybníček M, Cermák P, Prokop O, Zid T, Trnka M, Kolár T (2016). Oak (Quercus spp.) response to climate differs more among sites than among species in central Czech Republic. Dendrobiology 75: 55-65. - doi: 10.12657/denbio.075.006

Sohar K, Läänelaid A, Eckstein D, Helama S, Jaagus J (2014). Dendroclimatic signals of pedunculate oak (Quercus robur L.) in Estonia. European Journal of Forest Research 133: 535-549. doi: 10.1007/s10342-014-0783-9

Spinoni J, Naumann G, Vogt VJ (2017). Pan-European seasonal trends and recent changes of drought frequency and severity. Global and Planetary Change 148: 113-130. - doi: 10.1016/j. gloplacha.2016.11.013

Stojanović DB, Levanič T, Matović B, Orlovic S (2015). Growth decrease and mortality of oak floodplain forests as a response to change of water regime and climate. European Journal of
Forest Research 134: 555-567. - doi: 10.1007/ s10342-015-0871-5

Stokes MA, Smiley TL (1996). An introduction to tree-ring dating. The University of Arizona Press, Tucson, USA, pp. 73. [online] URL: http:// books.google.com/books?id=SvBF2Ora-eUC Thornthwaite CW (1948). An approach towards a rational classification of climate. Geographical Review 38: 55-102. - doi: 10.2307/210739

Tobisch T, Kottek P (2013). Forestry-related databases of the Hungarian Forestry Directorate. National Food Chain Safety Office (NFCSO), Web site, Hungary. [online] URL: http://portal. nebih.gov.hu/documents/10182/862096/Forestr y_related_databases.pdf/3ffg2716-2301-4894ā24-72faf́cagd4fc

Tumajer J, Treml V (2016). Response of floodplain pedunculate oak (Quercus robur L.) treering width and vessel anatomy to climatic trends and extreme hydroclimatic events. Forest Ecology and Management 379: 185-194. doi: 10.1016/j.foreco.2016.08.013

Tóth T, Balog K, Szabó A, Pásztor L, Jobbágy EG, Nosetto MD, Gribovszki Z (2014). Influence of lowland forests on subsurface salt accumulation in shallow groundwater areas. AoB PLANTS 6: 1-15. - doi: 10.1093/aobpla/plu054

Török P, Tóthmérész B (2004). A Debreceni Nagyerdö növényzeti arculatának vizsgálata [Botanical survey of the Great Forest of Debrecen]. Természetvédelmi Közlemények 11: 107116. [in Hungarian with English abstract]

Wazny T, Eckstein D (1991). The dendrochronological signal of oak (Quercus spp.) in Poland. Dendrochronologia 9 (35): 35-49.

Wigley TML, Briffa KR, Jones PD (1984). On the average value of correlated time series, with applications in dendroclimatology and hydrometeorology. Journal of Climate and Applied Meteorology 23: 201-213. - doi: 10.1175/15200450(1984)023<0201:OTAVOC>2.0.CO;2

\section{Supplementary Material}

Movie S1 - Temporal stability of the growth-climate relationship in pedunculate oak. Results of the moving window correlation analysis between oak growth and precipitation during the growing season over the investigated period.

Link: Arvai_2348@supploo1.mp4 